\author{
JAROSEAW PAEKA \\ History Meeting House, Warsaw
}

\title{
THE THIRD WORLD WAR AS ENVISAGED BY POLISH GENERALS AT THE TURN OF THE 1950S AND THE 1960S
}

\begin{abstract}
This article gives an account of the military exercises code-named 'Tempest' and carried out in the autumn of 1961 by the army of the Polish People's Republic under the supervision of Soviet officers. In the course of the war game the Polish staff members were placed in charge of the Baltic Front which, was given the task of seizing control of Denmark and the northern parts of Holland and Germany. These were the first large scale military exercises (a separate Polish front) to be organized after 1956.

Keyw or ds: Warsaw Pact, the Polish people's army, cold war, Third World War, war game, NATO.
\end{abstract}

Towards the end of the 1940s the Cold War confrontation between East and West was gaining momentum. Stalin was readying himself for the outbreak of an armed conflict. The Polish army, to be used in the major theatre of war, had to be completely subordinated to the eastern sovereign. It had been integrated into the Soviet army to the extent that it almost became an integral part of it. ${ }^{1}$ The staff exercises which took place in May and July 1950 involved the establishment of an independent Polish front - a higher operation unit capable of carrying out strategic tasks. The front was designed to include all the Polish armies - an arrangement which was apparently different from the one existing during the Second World War, when Polish armies were subordinated to the Soviet front commanders. The independence granted to Polish units was however only illusory. Left in charge were Soviet officers who were simply wearing Polish uniforms, and the tasks Polish troops were required to carry out

${ }^{1}$ Andrzej Paczkowski, ‘Wojsko Polskie w Układzie Warszawskim. Od marzeń o Polskim Froncie do rzeczywistości stanu wojennego', Zeszyty Historyczne, 161, 2007, p. 150. 
were still defined and allocated by Moscow. The front was designed to consist of three hundred thousand soldiers. Following the stopping of the enemy's offensive in the central coastal area, Polish armies were to mount a counter-offensive, seizing control of the Kiel Canal and the southern part of the Jutland Peninsula. One of the divisions, supported by the Baltic fleet, was entrusted with the task of capturing Bornholm. The next stage of the whole operation consisted of taking control of the entire Jutland Peninsula and the Danish islands. ${ }^{2}$

As it turned out, the exercises guidelines became the basis for elaborating ways of using Polish troops in the future joint operations of the states of the Soviet bloc. However, no further work regarding the strategic planning and the formation of a separate Polish front was carried out in the first half of the 1950s. The existing plans provided for the establishment of two combined-arms armies and one airborne army, but the units of the Polish People's Republic were not envisaged to form a separate front. There were field exercises that involved the participation of the front and army staff, but Marshal Konstantin Rokossovskii was in command of the Central Front which, in addition to Polish armies, also included the Soviet Army North Group and the Soviet Army Group in Germany. ${ }^{3}$

The situation had changed in October 1956 following Władysław Gomulka's rise to power. Rokossovskii left Poland, accompanied by the majority of Soviet generals. Their positions were taken by Polish officers connected with Gomulka. Of course there was no question of Poland regaining sovereignty: the previous year had seen the formation of the Warsaw Pact. Its creation was conceived of as a response to the North Atlantic Treaty Organization, formed in 1949, and as an attempt to formalize the principles to be followed in the joint operations conducted by the Soviet bloc states. However, the way in which the Warsaw Pact was supposed to function was never precisely defined; Moscow carefully guarded decisions regarding the plans for future war and nobody but Soviet leaders had the right to deal with these matters. A Soviet general and Deputy Minister of the National Defence of the Soviet Union served as commander-in-chief of the United Armed Forces of the Warsaw Pact and Deputy Chief of the General Staff of the Soviet Union was appointed its chief of staff. Moreover, the staff of the United Armed Forces of the Warsaw Pact was created as late as 1969. Only once did Moscow impart information regarding the number of Soviet units to be included in the

\footnotetext{
${ }^{2}$ Paweł Piotrowski, ‘Front Polski - próba wyjaśnienia zagadnienia', Wrocławskie Studia z Historii Najnowszej, 6, 1999, pp. 223-34.

${ }^{3}$ Ibid., pp. 224-25.
} 
structure of the Warsaw Pact. It took place right after its creation. Never again were Warsaw, Prague or Budapest provided with similar data. ${ }^{4}$

The idea of using Polish troops in a future conflict was embedded in the Soviet war doctrine. The latter was decisively offensive. A massive nuclear attack was to be carried out on the opponent's military and industrial facilities; offensive operations, both on land, in the air and at sea, were to be undertaken with a view to destroying the enemy completely and to capturing its territories. ${ }^{5}$ Polish war doctrine and military planning depended on those prepared by the Soviet Union; Polish commanders had no say in determining its final shape. All they could do was to influence the form and scope of Poland's involvement in the future conflict. Neither, it seems, was clearly defined in the mid-1950s. ${ }^{6}$ Following Gomułka's rise to power, attempts were made to define specific tasks to be carried out by Polish units. The First Secretary of the Central Committee of the Polish United Workers' Party wanted to make sure that the Polish armies would operate jointly in the future conflict, within a united front. Efforts were undertaken to elaborate a war doctrine, including an operational plan to be followed in the event of war. These efforts were particularly intensive at the turn of the 1950s and the 1960s. ${ }^{7}$

The first staff exercises carried out at the front level, with Marian Spychalski serving as Defence Minister, took place in 1959. During these exercises Polish tactical formations were entrusted with limited tasks and the fighting took place in Polish territories. The "westerners" army carried out a pre-emptive strike, attacking Polish coast and disembarking troops in Szczecin, Kołobrzeg and Gdynia. Following this attack, the troops of the North Army's Group seized bridgeheads on the eastern bank of the river Vistula. As a result of a strong resistance, coupled with air strikes, the "easterners" army succeeded in stopping the enemy on the line of the lakes, twenty kilometres east of Olsztyn, the Dąbrowa Wielkopolska lake, Gorzno, Rogowo, near Lipno and Włocławek. In addition to the employment of

${ }^{4}$ In 1955 out of a total of 78 divisions that made up the Warsaw Pact, there were 32 Soviet and 14 Polish ones. To this one must add 42 fighter aircraft divisions (22 Soviet and 7 Polish ones), 8 assault aircraft divisions (3 Soviet and 2 Polish ones), 11 bomber divisions (9 Soviet and 1 Polish ones). See Jerzy Poksiński, 'Memorandum Sztabu Generalnego WP w sprawie Układu Warszawskiego oraz planu rozwoju Sił Zbrojnych PRL na lata 1955-1965', Przeglad Historyczno-Wojskowy, 2000, 1, p. 82.

${ }^{5}$ Jerzy Kajetanowicz, Polskie wojska lądowe w latach 1945-1960. Skład bojowy, struktury organizacyjne, uzbrojenie, Toruń, 2005, pp. 294-95.

${ }^{6}$ Idem, Wojsko Polskie w systemie bezpieczeństwa państwa 1945-2010, Częstochowa, 2013, pp. 43-44.

7 Sztab Generalny (Główny) Wojska Polskiego 1918-2002, ed. Tadeusz Panecki, Franciszek Puchała and Jan Szostak, Warsaw, 2003, pp. 233-34. 
delay and defensive tactics, the 'easterners' regrouped their forces in the interior of Polish territory and readied themselves to counter-attack.

Polish troops were to be grouped together within the Mazury Front. Two armies - the 3th and the 6th, along with some selected units, were to halt the westerners' advance, while another two armies - the 5th and the 7th - were relocated with intent to launch a counter-attack from the country's interior. As envisaged in the exercises scenario, the westerners' troops reached the above mentioned line on 16 August 1959 and the counter-attack of the four combined-arms armies and one airborne army was launched on 19 August. The counter-offensive from the country's interior was accompanied by the First Baltic Fleet's disembarkation of its troops in the region of Ustka and Kołobrzeg on the fifth or sixth day of the operation. At the same time the westerners' units were destroyed in the region of Mraqgowo, Olsztynek and Ostróda, and so were their reserves. The latter suffered defeat near Nakło and Wałcz. Thus between the twelfth and the fourteenth days of the operation the Mazury Front seized control of the Baltic coast from Gdańsk to Szczecin, including some bridgeheads on the western bank of the river Odra. In the following stages of the operation, the bridgeheads were to be used as a basis from which to launch an offensive action westward. ${ }^{8}$ The exercises were carried out under the watchful eye of the representatives of the Soviet Army's General Staff. However, as General Józef Kuropieska, at that time commander-in-chief of the Warsaw Military District, recalled 'the exercises were of little benefit because nobody was actually well versed in that kind of thing'. ${ }^{9}$

Other documents regarding the front level exercises, code-named 'Łaba' (Elbe), date from 1960. The exercises took the form of a map war game that, for the first time after Rokossovskii left Poland, involved the conduct of offensive operations in the direction of West Germany. ${ }^{10}$ Their plan was first drafted in January. Amended in July and October, it was constantly updated. Under the plan, the NATO states were again the first to begin the preparations for war. In all the documents containing descriptions of particular exercises the westerners' troops are always given the role of those who strike first, with the Warsaw Pact units only responding

${ }^{8}$ Archiwum Ministerstwa Obrony Narodowej (henceforward referred to as A MON), 18/91/16, 'Założenia operacyjne do ćwiczeń na temat: Organizacja i prowadzenie działań dywersyjno-rozpoznawczych w operacji zaczepnej Frontu z 31 VII 1959', fols 1-5.

9 'Wielkiego pożytku z tego ćwiczenia nie było, bo nikt się na tym naprawdę nie znał', Józef Kuropieska, Od października do marca, Warsaw, 1992, p. 201.

${ }^{10}$ It was probably the first time since 1950 that this kind of exercises had been held. See Kajetanowicz, Wojsko Polskie, pp. 43-44. 
to the attack carried out by NATO. On the other hand, however, almost no defensive operations were practised, only offensive ones. ${ }^{11}$

Immediately after winning the border battle, so the plan went, the Baltic Front's main forces were expected to mount an attack in the direction of Ludwigslust, Brema and Quakenbrück, and to destroy Army Group North, seizing control of Hamburg and reaching the German-Danish border and the Baltic Sea coast from Trawemünde to Flensburg and the North Sea coast from the North Frisian Islands to Wezermünde. Interestingly, Denmark was to be attacked only if its neutrality were infringed by the NATO troops or if its territories were used in the operations directed against the easterners - and Denmark was a NATO member. The decision to cross into the Jutland Peninsula was to be taken by the Joint Command of the Armed Forces of the Warsaw Pact.

On the ninth or tenth day of these operations, the Warsaw Pact troops were to seize control of the northern part of the Federal Republic of Germany and the Netherlands, as far as estuary of the river Rhine, and then to proceed to the conduct of an anti-landing operation from the coastal border area between Germany and Denmark to the river Rhine - a move which protected the right wing of the other Warsaw Pact fronts. ${ }^{12}$ These goals could be achieved through the massive use of nuclear weapons. In order to cover these operations, the Baltic Front initially received 70 nuclear warheads (of which 50 were to be used for the front's more 'imminent' tasks and 20 for more 'distant' ones). In the October 1960 plan, this number was increased from 70 to $120 .{ }^{13}$ In addition to the nuclear units to be used along particular fronts, the airborne army received five atomic bombs to carry out retaliatory strikes and to gain the upper hand in the air. ${ }^{14}$

During the tenure of Gomulka and Spychalski, the Polish Front's first complex and large scale command-staff exercises were held in 1961. The scale of the exercises and the importance attached to them was linked with the events that took place during the Berlin crisis. The government of the German Democratic Republic sealed off Berlin's western sections by erecting a wall. Warsaw Pact troops were put on standby. On 21 September the Polish Minister of National Defence issued an operational directive

${ }^{11}$ Parallel History Project on Cooperative Security, 〈http://www.php.isn.ethz. ch/lory1.ethz.ch/collections/colltopic372b.html?lng=en\&id=20667\&navinfo=15708 $\rangle$ [accessed 25 March 2015], Conversation with General Jan Drzewiecki, 8 May 1997, p. 4.

12 A MON, 18/91/40, “Ćwiczenia “Łaba”. Założenia ogólne', fols 1-7.

${ }^{13}$ Ibid., fol. 6.

${ }^{14}$ A MON, 18/91/40, 'Dyrektywa operacyjna nr 001, Sztab Frontu Nadbałtyckiego, Włocławek, 22 VI 1960’. 
on the formation of the front's command, three combined-arms armies and one airborne army. The plan stated that all tactical units should be formed by 25 September. ${ }^{15}$ General Tadeusz Pióro, who at the time served as commander-in-chief of the Pomeranian Military District, recalled that in September in Wünsdorf, in the headquarters of the Soviet Army Group in Germany, a great staff game was held. Representatives of the Polish front's command were invited to take part in it. Pióro wrote years later: 'we were handed the guidelines of a huge offensive extending from the river Elbe to the coast of Atlantic Ocean. The central concentration of the Warsaw Pact army had its right wing leaning against the Baltic Sea, while the left one was stretching to Switzerland and the Pyrenees, with the exclusion of Spain which at that time was not a NATO member. We were expected to act out the annexation of almost all western Europe. The plan of the offensive involved the seizure of the whole of the Baltic Sea and the conduct of a covering landing in Norway'. ${ }^{16}$ Initially, the Polish front was included in the second wave of the operation, following the Soviet armies. However, after Spychalski's intervention Polish soldiers were ordered to join the first-wave Soviet fronts in carrying out the attack. Poland's communist rulers considered this assignment to be a cause for pride - East German armies were kept in the rear and the Czechoslovak armies were assigned to the Soviet front. Pióro added that there was only one set of documents turned over to the Soviet General Staff after the exercises, all the other copies and notes documenting the whole event were formally destroyed.

At the turn of September and October, the command staff exercises code-named 'Burza' (Tempest) were carried out in Poland. In reality it was a war game organized at the highest level of the Polish command. Held probably right after the staff game described above, it drew on the observations made in Wünsdorf. The General Staff managed to develop some doctrinal principles named: 'The basic concepts of the people's defence'. In many respects the principles followed those developed by the Soviets. Nuclear weapons were likely to be used in the future conflict that the document conceived in terms of a coalition war. The question of defensive

\footnotetext{
${ }^{15}$ Piotrowski, 'Front Polski', p. 227.

16 'wręczono nam założenia do potężnej ofensywy, zaczynającej się na Łabie i sięgającej po Atlantyk. Centralne zgrupowanie wojsk UW opierało się prawym skrzydłem o Bałtyk, lewym sięgało po Szwajcarię i Pireneje, z pominięciem Hiszpanii, która w tym czasie nie była członkiem Paktu Północnoatlantyckiego. Mieliśmy więc rozegrać aneksję całej prawie zachodniej Europy. W planie ofensywy przewidziano całkowite opanowanie Bałtyku i desant osłonowy na Norwegię', Tadeusz Pióro, Armia ze skaza. W Wojsku Polskim 1945-1968 (wspomnienia i refleksje), Warsaw, 1994, p. 343.
} 
capability was viewed as concerning both foreign and domestic policy, including all aspects of social and economic life. The country's war preparations focused on the selection of operational units to be included in the United Armed Forces of the Warsaw Pact (the so called exterior front) and the units to be placed under the national command and entrusted with the task of defending the country's territory. ${ }^{17}$ The idea of such a division was an original Polish contribution to military thought. ${ }^{18}$

According to this doctrine, operational troops should be acting on the plans developed by the Command of the United Armed Forces of the Warsaw Pact. Of course, the best trained and best equipped units were selected to join these united forces. We do not know the plans of the whole operation prepared by Soviet Marshals. Relevant documents are still closely guarded in Moscow. However, Polish documents concerning the exercises are readily available. ${ }^{19}$ Following the suggestions and directives they received from Moscow, Polish generals attempted to develop a Polish operational plan. It was informed by the guidelines adhered to during the 1951 exercises and by the analysis of the 'Tempest' war game carried out in 1961. The latter provide a clear picture of the Coastal Front. It is difficult to determine the extent to which it was consistent with the Soviet plans. ${ }^{20}$ However, let us take a look at the way the operation was envisaged by Polish staff officers elaborating their plans in consultation with Moscow. Its guidelines were used in the Polish

17 Sztab Generalny (Główny), pp. 234-35. See also Lech Kowalski, Komitet Obrony Kraju (MON-PZPR-MSW), Warsaw, 2011, pp.121-67.

18 On the Country's Territorial Defence forces see Franciszek Puchała, Sekrety Sztabu Generalnego pojattańskiej Polski, Warsaw, 2011, pp. 85-104.

${ }^{19}$ Documentsregarding the operational planning and the exercises carried out by Polish units selected to join the United Armed Forces of the Warsaw Pact are probably all preserved. They form different collections and are kept in the holdings of the Archive of the Ministry of National Defence and the Archive of the Institute of National Remembrance. The documents comprise all kinds of orders, reports, the exercises plans and maps.

${ }^{20}$ In the 1980s, General Wacław Szklarski, Chief of the Operational Board of the General Staff, recalled that Polish plans formed something of a camouflage operation. The commands of the allied states consulted Moscow for such plans. However, the General Staff of the Soviet Army probably used different documents whom nobody but the Russians had ever been allowed to see. See Krzysztof Dubiński and Iwona Jurczenko, Oko Pentagonu, rzecz o pułkowniku Ryszardzie Kuklińskim, Warsaw, 1995, p. 72. Colonel Julian Babula, Deputy Chief of the Mobilization Board of the General Staff, holds a completely different view of the whole thing. In one of his publications on the operational plans of the Polish People's Army after the Second World War he wrote: 'I believe that one is not justified in claiming that the Polish Front was fictitiously used'. At the same time he provided some arguments to corroborate his opinion. See Julian Babula, 'Zadania operacyjne Frontu Polskiego (Nadmorskiego) - fikcja czy rzeczywistość, 1959-1989’, Przegląd Historyczno-Wojskowy, 2010, 3, p. 242. 
operational plan. Its draft was accepted in 1964 and its final version one year later. ${ }^{21}$

The organizational structure of the front's staff received a seal of approval in the spring of 1961 . The structure was based on that of the General Inspectorate for Training of the Ministry of National Defence. The command was designed to consist of the staff, the artillery command and the heads of anti-aircraft defence, military engineering, car service, technical service, chemical units and quartermaster detachment - 737 military men and 158 civilians. ${ }^{22}$ General Zygmunt Duszyński, who served as Chief of the General Inspectorate for Training and the Deputy Minister of National Defence, was appointed commander of the Coastal Front, and general Jan Śliwinski, the First Deputy Chief of the Inspectorate, became the Chief of Staff. General Zdzisław Bobecki served as Chief of the Front's Operational Command.

It was stated in the exercises guidelines that towards the end of September 1961 the international situation grew tense, and the westerners began the secret mobilization of their troops. The Warsaw Pact states faced an increasing number of provocations and their borders were increasingly encroached on. Therefore, the Polish Minister of National Defence ordered the secret mobilization. The two first-wave armies were given a few days to obtain combat readiness in the region of the exercises. ${ }^{23}$ On 2 October at 8 p.m. the troops should be assembled and ready to go into action. ${ }^{24}$ The number of soldiers to be used on the front was 437,000 . They were equipped with over 1,500 tanks, almost 2,400 pieces of artillery and almost 360 planes. ${ }^{25}$

During the relocation operation one day was set aside for the allied troops (implicitly Soviet) to cross Polish territory. The relevant order stated that after two days of their redeployment, Polish troops should leave, on the third day of this operation, selected roads and areas. During

${ }^{21}$ The draft of the plan, entitled 'Plan operacyjny wojsk Frontu OP-61' was accepted in 1964. Its final version was accepted in February 1965.

${ }^{22}$ Piotrowski, 'Front Polski', pp. 226-27.

${ }^{23}$ The dates in the documents are slightly different from each other, especially those regarding the beginning of the exercises. Date changes introduced to the war game were handwritten. The dates were shifted from October to November. Sometimes the exercises progression is not linear, that is, the tasks to be carried out by specific units are slightly modified in the subsequent documents. However, the specific goals to be pursued during the staff exercises can be easily identified. The dates given in the article are those that originally appear in the documents.

${ }^{24}$ A MON 18/91/40, 'Dyrektywa operacyjna 001, Sztab Frontu Nadbałtyckiego, Włocławek, 22 VI 1960', fol. 6.

${ }^{25}$ A MON 18/91/40, 'Ogólne zestawienie stanu osobowego i sprzętu Frontu Nadmorskiego na godz. 20, 10 X 1961', fol. 222. 
the relocation of the allied units across Polish territory, the Poles should organize road services and secure communication: 'duplicating bridges across the rivers Vistula and Odra and allocating specific materials, communication means and hospitals, all of which serves the purpose of safeguarding the allied armies'. ${ }^{26}$ Seventeen different routes were mapped out for the Soviet units marching across Polish territory. Most of them ran from east to west, in the direction of GDR, along the Coastal Front line. Some, however, ran in the south of the country, along the strip of land to be occupied by the Soviet Western Front, including from Poland's eastern border to the border-crossing points in the western part of the country, in the direction of Czechoslovakia. ${ }^{27}$

In the evening of 2 October, the 51st and 52nd first-wave armies should be concentrated in the region of Koszalin, Szczecin, Kostrzyń, Poznań and Piła. This was the way in which strong operational units were made ready to strike from both the planned departure points as well as from the emergency areas, 'without any halt'. Armies should consist of three divisions to be used in the first-wave operations. Attacking on the front right flank were three divisions that made up the 50th Army: the 31 st Armoured Division (in reality the 20th Armoured Division), ${ }^{28}$ the 19th (8th) Mechanized Division and the 23rd (12th) Mechanized Division. These three divisions should be ready for redeployment across the river Odra. The Army's second wave comprised the 27th (16th) Armoured Division and the 34th (23rd) Infantry Division. ${ }^{29}$ The 51st Army was concentrated south of the Schwedt-Mirosławiec-Torun-Pasłęk line. Its first wave units comprised the 16th (5th) Armoured Division, the 22nd (11th) Mechanized Division and the 15th (4th) Mechanized Division, and its second-wave troops included the 21st (10th) Armoured Division and the 13th (2nd) Mechanized Division. The first-wave armies were followed by the 52nd Army which consisted of the 12th (1st) Mechanized Division, the 26th (15th) Mechanized Division, the 14th Infantry Division and 20th (9th) Infantry Division. Between 7 and 10 October the second wave army

${ }^{26}$ A MON 18/91/30, 'Założenia do dowódczo-sztabowego ćwiczenia "Burza” dla Wojska Polskiego z 28 IX 1961', fols 1-3.

${ }^{27}$ A MON 18/91/30, 'Zestawienie marszrut przegrupowania wojsk sojuszniczych przez terytorium PRL', undated, fols 15-16.

${ }^{28}$ The rule followed during the exercises was that to the real number of tactical units one added the number 11. NATO's intelligence must have known the force and structure of the Polish People's Army, but the way in which this information was encoded seems quite primitive. See A MON 18/91/30, 'Jednostki rakietowe Frontu Nadmorskiego i zasady numeracji związków taktycznych i oddziałów', undated, fol. 4.

${ }^{29}$ A MON 18/91/30, 'Dyrektywa operacyjna 001, Sztab Frontu Nadbałtyckiego, las zach. Nieporętu, 21 IX 1961', fols 145-51. 
should reach the region of Kościerzyna, Bydgoszcz, Piła, Stargard. The 17th (6th) Airborne Division was assigned to no army. Concentrated in the region of Więcbork, Nakło, Wysoka and Złotów, this division was to operate apart from other units.

The Navy was subordinated to the Command of the Baltic Fleet. The 53rd Airborne Army consisted of the 20th (9th) Air Fighter Division, the 22nd (11th) Air Fighter Division, the 19th (8th) Fighter Assault Division, the 27th (16th) Fighter Assault Division and the 26th (15th) Bomber Division. At the time of the relocation of combined-arms armies, the airborne army should become involved in defending the country's airspace and should be prepared to carry out retaliatory strikes, reconnaissance missions (using reconnaissance planes) and the ferry flights of aircrafts to alternate airfields. ${ }^{30}$ The general task with which the airborne army and the anti-aircraft defence was entrusted was to secure the relocation of the Coastal Front.

Missile units constituted the main striking force and, supported by the artillery, were expected to enable the forward movement of Polish divisions. Until the morning of 30 October missile units were concentrated in the following regions: the Independent Battalion of Operational-Tactical Missiles near Choszczno and Schwedt; the 35th Brigade of Operational-Tactical Missiles near Goleniów; the 54th Brigade of Operational-Tactical Missiles near Cechów and Mieszkowice; the 55th Brigade of Operational-Tactical Missiles near Więcbork.

Engineering troops should be ready to secure the crossing of the rivers Vistula, Oder and Warta, and to arrange ferry and pontoon crossings. Before the launch of the offensive, the front command should be set up ten kilometres to the south-west of Torun. ${ }^{31}$

As was the case with all the plans regarding the Polish front, the westerners were the first to attack. The Warsaw Pact troops put up defence and carried out retaliatory strikes. The NATO troops were to launch their offensive on 6 October at 12.10 p.m. It was to be preceded by nuclear strikes targeting Polish and Soviet combat troops as well as a number of facilities, especially in the territory of the GDR, but also in western Poland. The nuclear attacks were followed by the westerners' troops crossing into GDR territory. There ensued a border battle. In the evening of 6 October the NATO's Army North Group, specifically the 1st West Germany Army Corps

${ }^{30}$ A MON, 18/91/30, 'Skład bojowy wojsk operacyjnych Frontu Nadmorskiego, załącznik nr 1 do pisma 00110 z 28 IX 1961', fols 320-25.

${ }^{31}$ A MON, 18/91/30, 'Założenia do dowódczo-sztabowego ćwiczenia "Burza" dla Wojska Polskiego z 28 IX 1961', fols 1-3. 
and the 1st British Army Corps reached the Salzwedel-Wittenberge-Perleberg-Ludwigslust line, thus advancing ten kilometres into East German territory. However, this is where the Soviet Army Group in Germany and the GDR's Army, both of which formed the Central Front, stopped the westerners' offensive.

In detail the westerners' nuclear attack on Polish territory proceeded in the following way: Carried out between 12.10 and 12.40 p.m., it targeted the area of the concentration of the 50th Army. Nuclear charges/ shells were dropped on Szczecin, Szczecin-Dąbie, Gryfino, Pyrzyce, Banie, Stare Czarnowo and Stargad Szczeciński. However, the attack failed to destroy operational forces. The losses were inflicted mainly on the 31st Armoured Division, with 15 per cent of its soldiers killed and 20 tanks, 211 cars and 6 infantry combat vehicles destroyed. Following the deactivation, decontamination and some sanitary interventions, all of which had been completed by 7 p.m., the army began to cross over to the western bank of the river Odra. By midnight the main columns of the 19th Mechanized Division had reached the region of Greifswald and Anklam. The 23rd Mechanized Division moved furthest west, reaching the region of Krakow am See and Güstrow. In the evening of the same day, the 31st Armoured Division was in Penzlin, ten kilometres west of Neubrandenburg, and the 27th Armoured Division, which reached the area of Nowogard and Stargard Szczeciński, was being relocated in the rear.

As a result of the enemy's nuclear strike, the 51st Army lost 10 per cent of its soldiers and 4 tanks. At the same time, between 12.40 and 1.50 p.m., the enemy launched a nuclear attack on the bridges area in Siekierki, Kostrzyń and Świecie, including on the roads running towards Frankfurt on the river Odra. The tactical units of this army, just as those of the previous one, began its relocation to the western bank of the river Odra. Now both the 50th and the 51st armies were poised to mount a counter-offensive.

The nuclear strike inflicted no losses on the 52nd Army that formed part of the second wave troops. The 12th Mechanized Division and the 26th Mechanized Division moved, as planned, across the river Vistula and were now in the region of Piła. However, both divisions could not continue their movement because of the area's strong radioactive contamination. The 14th Infantry Division and the 20th Infantry Division remained in their positions.

The 53rd Airborne Army carried out a reconnaissance of the coastal area and cleared the airfields of the effects of the nuclear strikes. ${ }^{32}$ As

${ }^{32}$ A MON 18/91/30, 'Operativnoe donesenie Shtaba Primorskogo Fronta nr 08, las 
a result of the strikes it lost 32 planes and 16 airmen. The losses suffered were not great because, as is stated in the report, Polish units 'remained hidden and in armoured vehicles'. The radiation doses received by the soldiers were low and did not affect their capacity to carry out their tasks. Six hours after the strike Polish soldiers were able to leave their shelters and continued their redeployment.

Further strikes were carried out by the westerners after midnight, on 7 October. Nuclear bombs were dropped on the same regions. This time, however, the bombs failed to reach their target, for both first-wave armies had already crossed the river Odra, thus leaving the region that came under attack. Most units of the 52nd Army had not yet left their original positions. At the same time the units that found themselves within the strike zone 'took advantage of the existing shelters, thus frustrating the enemy's efforts'. Finally, the westerners' last nuclear attack, carried out in the initial phase of the war, on 7 October at 1 p.m., was significantly weaker and, as such, did not cause much damage. The river Odra crossings were attacked. Individual nuclear attack also targeted two first-wave divisions operating in the territory of the GDR. However, these attacks did not hinder these units from continuing their offensive. It was stated that: 'by monitoring the scale of radioactive contamination and by avoiding strongly polluted areas, coupled with the use of anti-contamination protective clothing, the units of the 50th and 51st armies managed to carry out their tasks'. ${ }^{33}$

All these plans seem to have been not only unrealistic but even bizarre. It is to be wondered at why their authors had such a low opinion of the opponent's intelligence work. The "westerners" two nuclear strikes were expected to be completely unsuccessful. Why were Polish staff officers so convinced of the effectiveness of the protection against the effects of nuclear attacks? Did they hope to survive the attack, including its effects, by hiding in the ground shelters, cars and armoured vehicles? At that time the amount of combat vehicles resistant to nuclear weapon was very small. Interestingly, it seems that in 1961 no thought was given to the idea of building a nuclear bunker for the front's command. The order regarding the protection of the staff against the weapon of mass destruction included the following opinion: 'terrain's protective properties such as cliffs, hills

15 km na płd. od Szwerina, 6 X 1961, godz. 24.00', fols 275-77 (the document in Russian was for the High Command of the United Armed Forces of the Warsaw Pact).

33 'prowadząc ciągłe rozpoznanie skażeń i obchodząc miejsca o wysokim natężeniu promieniowania przy równoczesnym wykorzystaniu indywidualnych środków ochrony przed skażeniami, wojska 50-tej i 51-szej A[rmii] wykonały swoje zadania', A MON, 18/91/30, 'Sprawozdanie operacyjne nr 01, Sztab Frontu Nadmorskiego, godz. 20.00, 8 X 1961', fols 452-53. 
and counter slopes should be taken into account in the choice of command post'. ${ }^{34}$

However, it is the scale of these attacks that needs to be paid attention to in the first place. 21 nuclear-armed missiles with a total force of 2,048 kilotonnes were to be dropped on Polish territory on 6 October. On the following day the strength of the westerners' strike was to be twice as big. This time 44 nuclear-armed missiles with a total power of 4,787 kilotonnes were envisaged to hit Poland. The missiles to be fired against Poland on 6 and 7 October were, taken together, assumed to have a force of $6,835 \mathrm{ki}$ lotonnes. ${ }^{35}$ To compare, the bomb dropped on Hiroshima had a force of 16 kilotonnes. It seems that at least western Poland would have been turned into a nuclear desert as a result of the westerners' attack. And the plan envisaged no significant losses to be suffered by the front's armies, which continued their redeployment. Was such a scenario possible? Was it really how Polish and Soviet officers imagined such an operation? And perhaps NATO's pre-emptive strike was only a mock element of the exercises. Perhaps nobody gave any serious thought to this, and the idea of such an attack served only as a justification for the offensive/counter-offensive to be carried out by the easterners. In reality the war would have started with a nuclear attack carried out by the Warsaw Pact - an option which left one justified in assuming minimal Polish losses (almost none). On the other hand, however, the documents regarding the exercises were strictly confidential, created for internal use only. Why would anyone want to add some unrealistic elements to them?

At any rate, the plan on which the 'Tempest' exercises were based assumed that the redeployment of the 50th and 51st armies would be accompanied by the movement of missile troops. As a result of the westerners' strike only one missile launcher was destroyed and one suffered damage. The launchers belonged to the 54th Operational-Tactical Missiles Brigade. On 6 October at midnight there were 78 missile sets ready to be launched. The offensive of the Coastal Front could be started.

In October 1961 the front's commander wrote in his order: 'In order to complete the tasks the land and air operations will be carried out hand in hand with a nuclear-missile attack, and combined air and naval landing

34 'przy wyborze SD wykorzystać właściwości ochronne terenu, jak urwiska, wzgórza, przeciwstoki', A MON, 18/91/30, 'Zarządzenie obrony przed środkami masowego rażenia SD Frontu nr 1, 28 IX 1961, godz. 23', fol. 186.

${ }^{35}$ A MON, 18/91/30, 'Sprawozdanie z użytych środków jądrowych w czasie operacyjnym od godz. 12.006 X 1961 do godz. 13.008 X 1961', fol. 266. In another document, quoted above, the force of this strike was 5,092 kilotonnes. A MON, 18/91/30, 'Sprawozdanie operacyjne nr 01, Sztab Frontu Nadmorskiego, godz. 20.00, 8 X 1961', fols 452-53. 
operations, coupled with a propaganda campaign, will be conducted with a view to eliminating Denmark's participation in the war'. ${ }^{36}$ The whole counter-offensive was to be preceded by a massive nuclear strike. In the 1960s the Polish People's Army entered into possession of missile systems capable of carrying out nuclear missions over a distance of up to 300 kilometres at the operational level, and over a distance of up to 65 kilometres at the tactical level. The army was also equipped with Su-7 and MIG-21 aircraft capable of carrying nuclear bombs. However, Poland did not have a weapon of mass destruction. In the 1960s the Soviet Union was expected to transport this weapon to Poland. ${ }^{37}$ During the 'Tempest' exercises the limits were set at 93 missiles to be employed in the operations involving the use of nuclear charges, with 59 missiles for more 'imminent tasks' and 34 for 'more distant ones' ${ }^{38}$ It seems that these limits were raised in the course of the exercises. ${ }^{39}$

Relevant units were to be prepared to launch their first attack on 7 October at 7.30 a.m. During the initial phase of the operation, the air and naval landings on the Jutland Peninsula and Danish islands were to be supported by two strikes carried out with the use of the front weapons (200 kilotonnes) and three strikes carried out with the use of the army weapons (40 kilotonnes). This attack was code-named 'Odra'. The conduct of 31 nuclear strikes was ordered 'in order to safeguard the main battle formation' destined to operate in the key part of the front line: 14 with the use of divisional weapons (10-20 kilotonnes each), 14 with the use of army weapons (10-40 kilotonnes each) and 3 with the use of front weapons (10-40 kilotonnes each). The order regarding the

36 'zadania zamierzam wykonać połączonym wysiłkiem operacji rakietowo-jądrowych, lądowej i powietrznej, a dla wyeliminowania Danii z wojny dodatkowo przeprowadzić kombinowaną operację desantowo-powietrzną i morską oraz operację polityczno-propagandową', A MON, 18/91/30, 'Dyrektywa operacyjna nr 002, sztab Frontu Nadmorskiego, las 10 km na południowy-zachód Toruń, godz. 10.00, 4 X 1961', fol. 234.

${ }^{37}$ In practice it turned out to be too time consuming. Consequently three bunker compounds were built to stores such a weapon (this operation was code-named 'Wisła' (Vistula)). These bunkers were guarded by Soviet soldiers. After the outbreak of the war the weapon was to be turned over to the Polish units. The limits of nuclear warheads and nuclear bombs to be used by the Polish People's Army were determined by the Soviet General Staff. See Paweł Piotrowski and Tomasz Pompowski, 'Polska miała arsenał broni nuklearnej’, Dziennik, 26 January 2007, 〈http://wiadomosci.dziennik.pl/polityka/ artykuly/198972,polska-miala-arsenal-broni-nuklearnej.html $\rangle$ [accessed 20 March 2016] and Franciszek Puchała, Budowa potencjału bojowego Wojska Polskiego 1945-1990. Obszary szpiegowskich działań, Warsaw, 2013, p. 173.

${ }^{38}$ A MON, 18/91/30, 'Dyrektywa operacyjna nr 002, sztab Frontu Nadmorskiego, las $10 \mathrm{~km}$ na południowy-zachód Toruń, godz. 10.00, 4 X 1961', fol. 234-39.

${ }^{39}$ A MON, 18/91/30, 'Sprawozdanie z użytych środków jądrowych w czasie operacyjnym od 13.008 X 1961 do 11.009 X 1961', fol. 265. 
most powerful strike (500 kilotonnes) was to be issued later, depending on the situation on the front. The attack was to target the "westerners" units, the identified batteries armed with anti-missile warheads 'Zeus', the batteries of tactical missiles 'Honest John', the batteries of coastal artillery, nuclear weapon storage facilities, the detected concentrations of land units, the Hamburg airport and the staff of the 1st British Army Corps. Here too readiness to carry out missile attacks was set for 7.30 a.m. The attack to be carried out in the key part of the front line was code-named 'Rekin' (shark). ${ }^{40}$ At the same time the command of the Allied Forces were asked to carry out two strategic strikes on the harbours in Wezermünde (actually Bremerhaven) and Wilhelmshaven.

The Polish counter-strike against the westerners' missile units and the nuclear weapon storage facilities proved successful. The opponents' last massive nuclear assault took place, as indicated above, on 7 October at 1 p.m. During the following two days, at the height of the Polish offensive, the enemy carried out no nuclear attacks. At the same time, on 9 October, the radioactive contamination at 'zero points', that is, at the points at which nuclear attacks took place, was 5-8 rads/hour, with only $0.5 \mathrm{r} / \mathrm{h}$ at elsewhere. ${ }^{41}$ Given so huge an amount of nuclear weapons used during these operations, the question to be asked is whether these figures were not too optimistic. The exercise documents contained the suggestion 'to manoeuvre around the most contaminated areas. When such manoeuvres were out of the questions, the maximum admissible radiation intensity at the highest points of the contaminated areas could not exceed $200 \mathrm{r} / \mathrm{h}$ with transport vehicles moving at a speed of $12-15 \mathrm{~km} / \mathrm{h}$ and $30 \mathrm{r} / \mathrm{h}$ with soldiers marching at a speed of 3-4 km/h' ${ }^{42}$ Again one must ask oneself whether it was possible to arrange for such huge masses of soldiers to bypass the contaminated regions. On the other hand, soldiers staying in contaminated areas were going to suffer from serious radiation sickness. The

${ }^{40}$ A MON, 18/91/30, 'Meldunek dotyczący planowania uderzeń jądrowych wojsk rakietowych według danych na 7.00 na 7 X 1961 i uzupełnienia dyrektywy', fols 268-69.

${ }^{41}$ A MON, 18/91/30, 'Sprawozdanie z użytych środków jądrowych w czasie operacyjnym od $13.008 \mathrm{X} 1961$ do $11.009 \mathrm{X} 1961$ ', fol. $265.0 .5 \mathrm{r} / \mathrm{g}$ is $5 \mathrm{mSv}$ (milisievert). It is twice as much as a natural radiation level in Poland. A longer stay in the radiation zone of over 5-8 $\mathrm{r} / \mathrm{h}$ would cause clinical changes in human body. The reception of $100 \mathrm{r} / \mathrm{h}$ would result in acute radiation syndrome and death and the reception of $300 \mathrm{r} / \mathrm{h}$ would result in immediate death.

42 'organizując odpowiedni manewr. W przypadku braku warunków do manewru dopuszczalne natężenie promieniowania w najwyższych punktach skażonych stref, przy szybkości marszu w środkach transportowych $12-15 \mathrm{~km} / \mathrm{h}$ nie może przekraczać $200 \mathrm{r} / \mathrm{g}$, przy marszu pieszo 3-4 km/h - $30 \mathrm{r} / \mathrm{g}$ ', A MON, 18/91/30, 'Zarządzenie $\mathrm{nr}$... na zabezpieczenie przegrupowania Frontu Nadmorskiego, 29 IX 1961', fols 155-56. 
soldiers who were going to receive the radiation dose of $200 \mathrm{r} / \mathrm{h}$ were to be 'counted among the losses'. It was optimistically estimated that throughout the offensive carried out during the 'Tempest' exercises the number of such soldiers would be rather small. Only the soldiers of three divisions were going to be exposed to such a high radiation ( 3 per cent, 8 per cent and 25 per cent of all these three units respectively). The radiation doses received by men from the remaining divisions varied from 1 to $100 \mathrm{r} / \mathrm{h}$ (a significant range, it should be kept in mind that a radiation dose of $100 \mathrm{r} / \mathrm{h}$ results in acute radiation syndrome). 100 per cent of the soldiers from 4 divisions, 90 per cent of the soldiers from 2 divisions and 50 per cent of the soldiers from nine divisions, including three airborne ones, were assumed to receive a radiation dose of 1 to $100 \mathrm{r} / \mathrm{h} .{ }^{43}$ Tadeusz Pióro recalled that the Polish armoured and mechanized divisions taking part in the attack were to be preceded by chemical units cleaning contaminated areas, but 'the ineffectiveness of their efforts was quite obvious. The troops entered the areas of explosions a few hours after the latter took place, without taking into consideration the consequences of such an action'. ${ }^{44}$

It seems that damage inflicted as a result of a nuclear attack carried out by the westerners was underestimated, as were the losses resulting from the use of the easterners' own nuclear weapons. In reading relevant documents one gets the impression that the offensive operation was based on the lessons derived from the Second World War and nuclear weapons were thought of as changing the nature of war only to a small extent. The nuclear attack carried out by the enemy entailed losses similar to those inflicted by the artillery. The army could rely on manoeuvre warfare and bypass contaminated areas. On the other hand it cannot be argued that the use of nuclear weapons had no impact whatsoever on the way the war was pursued. First of all it gave the easterners the upper hand in the conflict and significantly increased the impact of artillery fire preparing the offensive. Artillery barrage was here turned into a nuclear missile strike which significantly diminished the enemy's resistance. Consequently, the Warsaw Pact troops actually proceeded to pursue the enemy. Also the death toll of the operation on Polish soldiers was not of crucial importance, with the Soviet Union and his allies having such 'huge human resources' at their disposal. The masses of anonymous soldiers carried out an attack and the units destroyed in its course could be replaced with new ones - an approach which

${ }^{43}$ A MON, 18/91/30, 'Dawki napromieniowania składu osobowego wojsk Frontu Nadmorskiego na godz. 1810 X 1961', fol. 361.

44 'bezskuteczność tego działania była oczywista, wojska wchodziły w rejon eksplozji po kilku godzinach, nie licząc się z konsekwencjami', Pióro, Armia ze skazą, p. 347. 
remained in line with the Second World War doctrine and which was to give the easterners an advantage in numbers, including in combat equipment (the latter was also quantitative). No thought was given to the radiation sickness from which a great number of soldiers would have suffered. The 'Tempest' plan also contained no information concerning the losses likely to be inflicted on the civilian population (after all the plan regarded military exercises), and these would have been tremendous.

Polish divisions were to go into action a few hours after the nuclear attack. Operating south of the Coastal Front was the Soviet Western Front entrusted with the execution of the main task in this theatre of war. Its main opponent was NATO's Northern Army Group - the Polish units would have fought against its left wing. The plan envisaged that the river Elbe would be crossed quickly. The specificity of the tasks to be carried out by the Polish Front required the two first wave armies to be split up and moved in two different directions, northward and westward. The conditions of the exercises should be, it was assumed, as close to reality as possible. With this in view, the command, the staff and the support units were redeployed over a long distance - after all this is how all of them were expected to act under real war conditions. They were expected to follow the attacking armies. On 4 October, General Jerzy Bordziłowski, Chief of the General Staff and General Sigfried Riedel, Deputy Minister of National Defence of the GDR, signed an agreement regarding the stay of the staff and of the support units in East German territory. ${ }^{45}$ Other documents were produced in the command post set up in the military training area near Schwerin, a short distance from the inter-German border. The exercises were held there, it seems, under the watchful eye of Marshal Aleksei Antonov, Chief of Staff of the United Armed Forces of the Warsaw Pact states. ${ }^{46}$

The order issued right after the launch of the counter-offensive contained the following remarks: 'exploiting the effects of the nuclear retaliatory strike', Polish divisions proceeded to carry out an offensive operation which proved successful. The order also stated that 'the enemy, having suffered heavy losses of soldiers and equipment, was forced to

${ }^{45}$ A MON, 18/91/30, 'Protokół dotyczący pobytu ćwiczących sztabów na terenie NRD, podpisany 4 IX 1961, fols 366-68.

${ }^{46}$ Julian Babula writes the 'Tempest' exercises were carried out in the territory of Czechoslovakia, the GDR, Poland and the Soviet Union. The available documents do not confirm such an opinion. From the documents it is apparent that Polish Staff members trained in the country and then in GDR. Participating in the exercises were the officers selected to join the High Command and the Staff support units. Julian Babula, Wojsko Polskie 1945-1989. Próba analizy operacyjnej, Warsaw, 1998, p. 242. 
withdraw in westward and northward directions. Two corps, one British and one German, were partly destroyed, having, however, preserved the force of almost two and a half divisions. One of the key tasks was to capture the bridges and equipment in the Kiel canal intact. The execution of the task was set for the night of 7 to 8 October. It was to be completed by the air and naval landing operations. The order went on to say: keep up the offensive by moving on to the operational pursuit and, in following nuclear strikes, seize control of the line of Danish fortifications'. The line of Oberno (probably Aabernaa)-Brede (probably Bredebro ${ }^{47}$ should be captured by the end of 8 October and that of Randers-Viborg-Struer by the end of the following day. The enemy was expected to maintain resistance only in the northern part of the Jutland Peninsula. The air landing operation on Danish Zealand was set for the morning of 7 October, to be followed by the launch of the naval landing two hours later. The air operation was to be carried out by the 17th Airborne Division landing in the region of the Køge. The unit was given the task of capturing Copenhagen which it was expected to fulfil in cooperation with the navy. In addition to Zealand, Fyn Island was also captured.

In the main western area of operations, troops were under orders definitely to pursue the enemy in the direction of Rotenburg-Oldenburg. Until dawn on 9 October all the bridgeheads on the river Weser were to be captured. At the same time the westerners were gathering a reserve force of four to five divisions to carry out a counter-attack in this area on 9 October. However, before entering the battle, they found themselves forestalled by Polish units, specifically by the front's second-wave strike carried out by the 52nd division. Initially concentrated in the region of Miastko, Piła, Bydgoszcz, Stargard Gdański, the army was redeployed westwards to launch an attack from the line of Granderkesse (probably Blankensee)-Barsdorf, north of Berlin, in the direction of Enschede-Rotterdam. The 52nd Army's entry into battle was to be preceded by ten nuclear strikes. By 10 October these units, taking advantage of the nuclear attack, were to capture the region of Genemuiden-Zutphen, thus reaching the river Ijssel in Netherland, and by 10 October, jointly with the 51st Army, to seize control of the whole of the Netherlands. ${ }^{48}$

In the evening of 10 October the front commander reported the success of the offensive and specified its next stages. However, the dates he

${ }^{47}$ Many geographical names that appear in the documents contain errors. Was this the result of typing problems or perhaps it was some form of encrypting data?

${ }^{48}$ A MON, 18/91/30, 'Zarządzenie nr 0042, Sztab Frontu Nadmorskiego, 8 X 1961', fols 158-59. 
set for the capturing of particular cities and regions by Polish units were different from those mentioned above. Based on the previous documents, the victory on the Jutland Peninsula was to be won by the end of 9 October and in the west by the end of 11 October. In the subsequent documents the dates are shifted by two days. Denmark should be eliminated from the war by 11 October and Netherlands should be taken by 13 October. In the evening of 11 October, the command post was established in the woods, ten kilometres northeast of Schneverdingen, near Hamburg. ${ }^{49}$

The report of 10 October contained information that the westerners still had two infantry divisions operating in the Jutland Peninsula - the 6th German Infantry Mechanized Division and the 3rd Danish Mechanized Infantry Division. The remains of one Danish division (the 6th Infantry Division) were defending themselves in the region of Copenhagen and one Infantry battalion was operating on the island Funen. On 10 October at 8 p.m. Polish divisions reached the line of Horsens-Tarm on the Jutland Peninsula, thus seizing control of over half of the peninsula. Here the final destruction of the westerners' troops by Polish units was to be preceded by a nuclear attack with a force of 73 kilotonnes against two divisions German and Danish ones. Following this attack the enemy was expected to lose 25 per cent of its troops. The 31st Armoured Division, taking advantage of the effects of the attack, was assigned the task of rapidly advancing in the direction of the northern cape of the peninsula. The task of the 17th Airborne Division was to seize full control of the islands of Zealand and Funen. Following the seizure of Copenhagen and the elimination of Denmark from war - a task to be completed by 11 October - the airborne unit and the 27th Armoured Division were expected to move to the rear of the front and the 31st Armoured Division should join the 51st Army ${ }^{50}$ In the following days the army should proceed to the establishment of the occupation administration of the captured territories. ${ }^{51}$

The main fighting was to take place in northern Germany and the Netherlands. That is where the remains of three corps: British, German and Dutch (4-5 divisions) ones were defending themselves, including three brigades surrounded in the region of Bremen. In western Netherland there were still 3 to 4 westerners' divisions defending the crossings

${ }^{49}$ A MON, 18/91/30, 'Zarządzenie nr..., sztab Frontu Nadmorskiego, las na płd. od Schwerina, 11 X 1961', fols 328-29.

${ }^{50}$ A MON, 18/91/30, 'Meldunek dowódcy Frontu Nadmorskiego według sytuacji na godz. $20.0010 \mathrm{X} 1961$ ', fols 221-23.

${ }^{51}$ A MON, 18/91/30, 'Zarządzenie nr..., sztab Frontu Nadmorskiego, las na płd. od Schwerina, 11 X 1961, fols 328-29. 
over the river Rhine. Yet again the decisive role fell to the missile units equipped with nuclear weapon. The attack was very powerful. Eight nuclear strikes with a force of 173 kilotonnes were to be carried out against the enemy surrounded in the region of Bremen and against the armoured division operating south of Wilhelmshaven. Each of the units was expected to suffer 45 per cent losses. An hour later an order was issued to carry out a strike against the harbours in Wilhelmshaven and Emden. Another three strategic strikes against the westerners' troops in the region of Utrecht with a huge force of 2,000 kilotonnes were planned on the following day at 1 p.m. Finally at 4 a.m. five tactical strikes with a force of 90 kilotonnes against the German division defending the crossing of the river Rhine in the area of Dortmund and Ems were ordered. The enemy was expected to suffer 35 per cent losses. Polish divisions were to go into action immediately after this nuclear attack. It would be more appropriate to say that Polish units' task was simply to seize control of specific territories. As envisaged in the plan of the exercises, by the end of 11 October the 51st Army was expected to destroy the last of the westerners' troops encircled in the area of Bremen and to rout the German corps, to 'clean' the coast area and to seize control of the harbours in Wilhelmshaven and Emden. After completing these tasks the 51st Army should redeploy south-east of Zwolle, waiting for further orders. At the same time, the army's units were to remain in readiness to continue the offensive in the direction of UtrechtCalais, that is, towards Belgium and northern France.

The 52nd Army also continued its operation, now forming part of the first wave troops. The 20th Infantry Division, which served as its vanguard, conducted the offensive in the direction of Almelo, Utrecht and the Hague. It was given the task of capturing the capital of Netherland and the Dutch coast in the region of the Hague. Part of the 52nd Army was ordered to move towards Leeuwarden and Groningen to seize the Dutch coast in that region..$^{52}$

That is how the Polish Front ended its campaign in Western Europe, at least as envisaged in the plan of the staff exercises elaborated in the autumn of 1961. In carrying out its tasks the Front managed to 'safeguard the northern wing of the Western Front operating in the region of Frankfurt, to enable the Baltic Fleet to freely operate in the North Sea and to prevent the enemy from disembarking its troops along the coast by capturing the harbours'. ${ }^{53}$ It should take Polish units five days to seize control

${ }^{52}$ A MON, 18/91/30, 'Meldunek dowódcy Frontu Nadmorskiego według sytuacji na godz. $20.0010 \mathrm{X} 1961$ ', fols 221-23.

53 'zabezpieczyć północne skrzydło Frontu Zachodniego działającego na frankfurckim kierunku, stworzyć warunki wyjścia i swobodnego manewru Bałtyckiej Floty 
of the whole Denmark and seven days to reach the Dutch coast. Thus Polish troops would have covered a distance of 850 kilometres, including 650-700 kilometres in combat. This means that the troops would have carried out the attack at an average speed of 100 kilometres per day. It is very impressive. But is it realistic? In the 'best' period of the Wehrmacht's offensive against the Soviet Union, the German army moved at a speed of a little more than 30 kilometres a day. Of course in the 1960s combat units were technologically more advanced than in the 1940s. However, the fact still remains that the army would have had to move three times faster than during the Second World War. It seems that the approach adopted in the following years was more realistic. In 1967, during the exercises code-named 'Lato' (summer), troops were assumed to move at a speed of 50-65 kilometres per 24 hours and 30-42 kilometres per 24 hours when nuclear weapons were not used. The offensive targets should be achieved, it was assumed, within a space of 10 to 13 days (15-18 days when the weapon of mass destruction were not used).$^{54}$ However, the last numbers also meant carrying out military operations at a very fast pace - a real Blitzkrieg. Were such plans realistic? Finally, the question one must ask is whether anyone in the Polish staff was aware of the consequences of conducting nuclear war? Such a war would have turned this part of Europe into a nuclear desert. Of course Polish generals only executed orders they had received from the Soviets.

Generally, war games did not change throughout the existence of the Warsaw Pact. The way the games were played was linked with the Polish operational plans (which in turn were embedded in the Soviet War doctrine) which were subjected to some slight modifications. ${ }^{55}$ Some corrections, more or less significant, were introduced in the following years. In the 1970s, for example, large scale landing operations were practised. In addition to Denmark, Polish troops were also expected to seize control of Norway. ${ }^{56}$ Some plans were made more precise and more realistic. Technologically more advanced weapons were introduced,

na Morzu Północnym oraz przez opanowanie portów na wybrzeżu nie dopuścić do podejścia i wysadzenia świeżych sił nieprzyjaciela', A MON, 18/91/30, 'Meldunek dowódcy Frontu Nadmorskiego według sytuacji na godz. 20.0010 X 1961', fols 221-23.

${ }^{54}$ A MON, 18/91/227, 'Legenda do planu operacji zaczepnej Frontu Wschodniego 042/C, 2 VI 1967', fol. 133.

${ }^{55}$ The 1970 operational plan was almost a copy of the 1965 plan. Significant changes can be seen only in the 1986 plan. See Kajetanowicz, Wojsko Polskie, pp. 48-49.

${ }^{56}$ This was the case with the 1977 exercises code-named 'Fala' (wave). The Coastal Front was also entrusted with the task of taking control of Norway. See AIPN, 1408/82, 'Mapa: Zamierzenia dowódcy Frontu Nadmorskiego na godz. 8.00, 7 VII 1977’, no pagination. 
which affected the process of planning. This was the case with the use of missiles that could hit their targets more precisely. There was also an increase in the number and force of nuclear weapon used in the front operations. However, the direction of Polish operations remained the same, and so did their offensive character. The Polish operational plans, and the exercises that went with them, changed significantly in the 1980s because of Poland's difficult economic situation. This undermined the country's position in the Warsaw Pact. The 1986 operational plan included two possible kinds of operations - offensive ones similar to the previous ones and a defensive one, to be carried out along the line of the rivers Odra and Nysa Łużycka. However, the Warsaw Pact was always destined to win.

(Translated by Artur Mękarski)

\section{Summary}

This article gives an account of the military exercises code-named 'Tempest' and carried out in the autumn of 1961 by the army of the Polish People's Republic under the supervision of Soviet officers. In the course of the war game the Polish staff members were placed in charge of the Baltic Front which, forming part of Warsaw Pact troops, was given the task of seizing control of Denmark and the northern parts of Holland and Germany. These were the first large scale military exercises (a separate Polish front) to be organized after Gomułka's rise to power. They were taking place in the period of high international tension, during the Berlin crisis. The operation of the Baltic Front was based on the plans elaborated by the Command of the Joint Forces of the Warsaw Pact. The offensive to be launched by the Polish troops was to be preceded by a massive attack of the missile troops using nuclear weapon. The Polish units were to secure the northern wing of the Soviet Western Front operating in the main Frankfurt direction, to enable, by capturing the Danish ports, the Baltic Fleet to manoeuvre freely in the North Sea and to prevent the enemy from landing in the coastline area. In the exercises scenario, the Polish troops were given five days to seize control of the whole of Denmark and seven days to reach the Dutch coast near The Hague, while remaining in readiness to continue the offensive operation in the direction of northern France. This article shows how Polish staff members imagined a future conflict between NATO and Warsaw Pact, including specifically the role to be played in it by Polish troops.

(Translated by Artur Mękarski) 


\section{Bibliography}

Babula, Julian, Wojsko Polskie 1945-1989. Próba analizy operacyjnej, Warsaw: Bellona, 1998.

Babula, Julian, 'Zadania operacyjne Frontu Polskiego (Nadmorskiego) - fikcja czy rzeczywistość 1959-1989', Przegląd Historyczno-Wojskowy, 2010, 3, pp. 234-42.

Baev, Jordan, 'The Build-up of the Warsaw Pact's Military Structures, 1955-1969', Military History Journal, 66, 1997, 5, pp. 56-77.

Dubiński, Krzysztof, and Iwona Jurczenko, Oko Pentagonu, rzecz o pułkowniku Ryszardzie Kuklińskim, Warsaw: Wydawnictwo Intryga, 1995.

Kajetanowicz, Jerzy, Polskie wojska lądowe w latach 1945-1960. Skład bojowy struktury organizacyjne uzbrojenie, Toruń: Europejskie Centrum Edukacyjne, 2005.

Kajetanowicz, Jerzy, Wojsko Polskie w systemie bezpieczeństwa państwa 1945-2010, Częstochowa: Akademia im. J. Długosza, 2013.

Kowalski, Lech, Komitet Obrony Kraju (MON-PZPR-MSW), Warsaw: Wydawnictwo Naukowe Semper, 2011.

Paczkowski, Andrzej, 'Wojsko Polskie w Układzie Warszawskim. Od marzeń o Polskim Froncie do rzeczywistości stanu wojennego', Zeszyty Historyczne, 161, 2007, pp. 146-62.

Piotrowski, Paweł, 'Front Polski - próba wyjaśnienia zagadnienia', Wrocławskie Studia z Historii Najnowszej, 6, 1999, pp. 221-33.

Pióro, Tadeusz, Armia ze skaza. W Wojsku Polskim 1945-1968 (wspomnienia i refleksje), Warsaw: Czytelnik, 1994.

Poksiński, Jerzy, 'Memorandum Sztabu Generalnego WP w sprawie Układu Warszawskiego oraz planu rozwoju Sił Zbrojnych PRL na lata 1955-1965', Przeglad Historyczno-Wojskowy, 182, 2000, pp. 81-89.

Puchała, Franciszek, Budowa potencjału bojowego Wojska Polskiego 1945-1990. Obszary szpiegowskich działań, Warsaw: Fundacja Historia i Kultura, 2013.

Puchała, Franciszek, Sekrety Sztabu Generalnego pojałtańskiej Polski, Warsaw: Bellona, 2011.

Sztab Generalny (Główny) Wojska Polskiego 1918-2002, ed. Tadeusz Panecki, Franciszek Puchała and Jan Szostak, Warsaw: Bellona, 2003.

Biography: Jarosław Pałka - PhD, he works at the Oral History Archive at the History Meeting House in Warsaw. Scholarly interests: biographical studies and military history, including the history of the army of the Polish People's Republic; email: j.palka@dsh.waw.pl. 